\title{
E-learning Program Effectiveness on Students' Learning Satisfaction at Telkom University Bandung
}

\section{Fetty Poerwita Sary and Oktavian Herlambang}

Faculty of Economics and Business, Telkom University

\section{Abstract}

The purpose of this research is to know how the effectiveness of the implementation of the e-learning program that was applied by Learning Development Unit, Telkom university, how the learning satisfaction perceived by the students who used the e-learning, and the influence of the effectiveness of the implementation of e-learning programs on students' learning satisfaction at Telkom University.This research used quantitative methods. Data were collected by using questionnaire which was distributed

Corresponding Author: Fetty Poerwita Sary f.poerwitasary@gmail.com

Received: 18 January 2019 Accepted: 24 March 2019 Published: 31 March 2019

Publishing services provided by Knowledge E

(c) Fetty Poerwita Sary and Oktavian Herlambang. This article is distributed under the terms of the Creative Commons Attribution License, which permits unrestricted use and redistribution provided that the original author and source are credited.

Selection and Peer-review under the responsibility of the First ELEHIC Conference Committee. to 100 students, who used e-learning, as respondents. To interpret the results of the research, the researchers used descriptive analysis and simple linear regression analysis. The result showed that the effectiveness of the implementation of the elearning program and the learning satisfaction were high. The implementation of the e-learning program also had significant positive effect towards the students' learning satisfaction, which means the higher the effectiveness of the implementation of elearning program, the higher students' learning satisfaction was.

Keywords: effectiveness, students' learning satisfaction, e-learning

\section{Introduction}

Higher education institution is a place where students gain knowledge during their study period. From the organization's point of view, the institution is an educational organization with the aim of processing raw materials to get good output and quality. In educational term, the raw material is the students and it becomes the responsibility of the college to help the students become more qualified when they graduated [1]. The human resource management in college should be able to run effectively and efficiently. Educational organizations are required to be able to process the available resources to be better and more developed. It is believed that human resources are the most important thing in the organization. Although the organization does not have 
the resources or wealth in the form of money, but as long as the human resources in it are educated, skilled, disciplined, diligent, are willing to work hard, and have a good work culture, the organization still has a very great opportunity to develop. Therefore, it can be concluded that educational institutions must have an effective way to be able to process human resources in it to produce qualified graduates. The effectiveness of an organization system including educational organizations greatly affects the performance in the organization. To improve the quality in educational organizations, the cooperation from all resources, such as from both lecturers and students, is highly needed.

Rusmini [2] stated that to improve the performance of higher education institutions, the support from all elements of leadership, lecturers, students, and support staff must be considered. In this study, the researchers focused on improving the of students' performance in using e-learning as one method of effective learning. According to Supardi [3], effective learning is a combination that consists of people, material, facilities, equipment and procedures directed to change the students' behavior towards a positive and be better in accordance with students' potential and differences to achieve learning objectives that have been set. Since learning facilities are considered important in improving the performance of the organization especially in processing the raw materials / students into better output. In globalization era, the development of science and technology grows rapidly. Technology has become an important need to facilitate people's daily life, technology is expected to be an organizational facility to accelerate the performance of the organization in processing the students into better outputs. For this research, the researcher chose Telkom university students to be the research object because Telkom students have used e-learning as a supporting tool in learning. There are two applications of e-learning, they are Moodle and IDEA. Moodle is the application for e-learning template; it was managed by learning development unit and IDEA is the application that was developed by the information system unit of Telkom University.

The preliminary research showed that the effectiveness of e-learning program experienced by the students and the learning satisfaction perceived by the students was low. Based on the result, the researchers were interested to examine more about the effectiveness of e-learning implementation and its influence toward students' learning satisfaction.

\section{Literature Review and Methodology}




\subsection{Effectiveness}

Effectiveness is the plan-based target achievement or plan compared with the realization of the results. Siagian [4] defines the effectiveness as the utilization of resources, facilities and infrastructure in a certain amount that is consciously set before to produce several goods. Meanwhile, according to Mahsun [5] effectiveness is the relationship between the output with goals or targets to be achieved. This definition is basically related to the achievement of goals or targets of the policy. Operational activities will be effective if the process of the activity reaches the ultimate goals and objectives of the policy.

Organizational effectiveness can be defined as the organizational level of achievement of short- and long-term goals based on competing organizational values. According to Chatab [6], the term of effective shows how good the process and measurement in achieving organization goals. The effectiveness should be judged based on the plan that can be achieved not the concept of maximum goals. The effectiveness based on measurement is how far the organization can achieve the goal. It showed a success of achieving the target from the beginning.

According to Sary and Wildani [7], effectiveness can be measured from the following indicators: Target achievement (the target can be achieved properly); Adaptability (adaptation ability can be seen from how far one can adapt to changes inside and outside); Job Satisfaction (a condition that can provide comfort and motivation for the members).The focus of this element is work and reward fit for high achievers and perform exceeds workloads); Responsibility (people can perform what is given based on the provision that has been made before, and can face and solve problems that occur with their work)

\subsection{Learning satisfaction}

Satisfaction is a pleasant or unpleasant emotional state that is displayed in a positive attitude toward various activities and responses to the external environment. Learning is a process that is conducted by individual to gain a whole new behavioral change, because of the individual's own experience in interaction with his environment.

According to Topala and Tomozii [8], learning satisfaction includes individual's feelings and attitudes toward the educational process and the perception level of individual desire fulfillment for learning, caused by learning motivation. Surya [9] suggests that there are several factors that influence student's satisfaction in learning that is: (1) learning result reward, (2) safety in learning, (3) adequate learning condition, (4) opportunity to 
expand, (5) personal relationships. According to Topala and Tomozii [8], from the analysis and synthesis of the current research, there are six factors that are assumed as valid learning satisfaction indicators. They are individual characteristics, material condition and learning facilities, teachers and instructional activities, learning outcomes, learning environment, relationships with colleagues

\subsection{E-learning}

E-learning is a process of learning where the learning is conducted online. It is in line with the statement from Naidu in Darmawan [10] that e-learning usually refers to the use of network-based information and communication technology in the implementation of teaching and learning. In addition to e-learning, there are several other terms used in describing the learning model like this such as online learning, virtual learning, distributed learning and web-based learning. Broadly, they all refer to how to make the process of teaching and learning by utilizing information and communication technology to facilitate asynchronous learning activities to be as good as synchronous learning activities. Kumar [11] defines e-learning as an arbitrary teaching and learning that uses electronic circuits (LAN, WAN, or internet) to convey instructional content, interaction, or guidance. There are also interpreting e-learning as a form of distance education conducted through the internet media.

\subsection{Relationship of effectiveness of e-learning program with learn- ing satisfaction}

Several studies conducted by researchers examined the relationship between the effectiveness and learning satisfaction. The effectiveness of e-learning implementation is associated with the techniques and strategies used to achieve goals optimally, precisely and quickly. The word "satisfaction" is derived from the Latin "satis" which means quite good and adequate. According to Kotler [10], satisfaction is the feelings of pleasure and disappointment of a person when comparing what he or she expects with the reality. Other research conducted by Darmawan [10] got the result that when the reality is lower than the expectation, it will cause poor effectiveness that leads to low satisfaction for students, other discoveries that related to effectiveness with satisfaction conducted by Suwastika [12] showed that the satisfaction is caused by the content, accuracy, form, ease of use and timeliness that make the effectiveness of learning so that it affects the high satisfaction for students in using e-learning. Based on the description of studies 
that have been described earlier, the researchers took the topic of research that is the influence of effectiveness on students' learning satisfaction in using e-learning.

\subsection{Framework and hypotheses}

Based on several theories that have been described above and previous studies which became the basis for making this research. The framework of this study comes from measuring instruments of variables to be studied.

The researcher will discuss the variable of effectiveness as independent variable (variable $X$ ) by using measuring instrument adapted from Sary and Wildani [7] covering target achievement, adaptability, satisfaction and responsibility. Then for students' learning satisfaction as the dependent variable (variable $Y$ ) used measuring instruments from Topala and Tomozii [8] consisting of individual characteristics, material conditions and learning facilities, teaching and instructional activities, learning outcomes, learning environment, relationship with colleagues. Below is the framework used in this study as in Figure 1:

\section{Learning Satisfaction (Y)}

1. Individual characteristics

\section{Effectiveness (X)}

1. Achieving targets

2. Adaptability

3. Satisfaction

4. Responsibility

Source: Sary and Wildani [7]
2. Material condition and learning facilities

3. Teachers and instructional activities

4. Learning outcomes

5. Learning environment

6. Relationships with colleagues

Source: Topala and Tomozi [8]

Figure 1: Framework.

\subsubsection{Hypotheses}

$\mathrm{H1}$ : There is a positive significant influence between the effectiveness of the implementation of e-learning program on the students' learning satisfaction. 
HO: There is no significant positive influence between the effectiveness of the implementation of e-learning program on students' learning satisfaction

\section{Research Methodology}

\subsection{Respondents}

The respondents for this research are students who used e-learning program managed by the Learning Development Unit of Telkom University. The method used is probability sampling with random sampling technique. The characteristics of respondents can be seen in the table 1 below:

TABLE 1: Demographic Factor.

\begin{tabular}{|l|l|c|c|}
\hline $\begin{array}{l}\text { Demographic } \\
\text { Factors }\end{array}$ & Klasifikasi & Respondents & Presentase \\
\hline Sex & Male & 50 & $50 \%$ \\
\hline Faculty & Econale & 50 & $50 \%$ \\
\hline & Communication and & 0 & $0 \%$ \\
\hline & Business & 18 & $18 \%$ \\
\hline & Creative Industry & 18 & $18 \%$ \\
\hline & Industrial Engineering & 17 & $17 \%$ \\
\hline Informatics Engineering & 15 & $15 \%$ \\
\hline Electrical Engineering & 17 & $17 \%$ \\
\hline Applied Science & 15 & $15 \%$ \\
\hline & 2013 & 3 & $3 \%$ \\
\hline 2014 & 45 & $45 \%$ \\
\hline & 2015 & 39 & $39 \%$ \\
\hline & 2016 & 13 & $13 \%$ \\
\hline
\end{tabular}

\subsection{Measurement}

To measure the two variables, this study used 13 items statement on effectiveness. While to measure the variable of learning satisfaction, it used 18 items statement about the learning satisfaction. The author uses a five-point Likert scale. The Likert scales used for the statement of effectiveness are (1), strongly disagree (2), strongly disagree (3), hesitate (4), agree (5), strongly agree, while for satisfaction statement is (1), very dissatisfy 
(2), dissatisfy (3), neutral (4), satisfy (5), very satisfy. Based on validity test, all statements declared valid. All statements are reliable with Cronbach's Alpha 0.816 for effectiveness variables, while the learning satisfaction is 0.912

\subsection{Analysis technique}

Data analysis technique used in this research is descriptive analysis and simple linear regression analysis. Descriptive analysis is required for the overall description of the object under study or a basic data transformation that describes characteristics such as central tendency, dispersion, and variability [13]. While linear regression analysis is used to determine the pattern of dependent variables that can be predicted through Independent variables [14].

\section{Discussion}

The result showed that if the value of constant $(\alpha)$ is 0,393 , the learning satisfaction will be 0,393 , while the positive coefficient value is 0,857 , stated that if the effectiveness of the implementation of e-learning program is high, then the learning satisfaction will be also high and vice versa if the effectiveness of the implementation of e-learning program is low then the satisfaction of learning will also be low. The researcher also conducted a correlation coefficient test to find out how close the relationship between the effectiveness of the implementation of e-learning program to the students' learning satisfaction and coefficient determinant test to find out how much the effectiveness of the implementation of e-learning program affects students' learning satisfaction in using e-learning program. The result of correlation coefficient $(R)$ is equal to 0,743 which means relation between effectiveness of implementation of e-learning program to students' learning satisfaction was in strong category. To find out how much the effectiveness of the implementation of e-learning program affects student's learning satisfaction in using e-learning can be known through coefficient of determination test, the result obtained is the coefficient of determination $\left(R^{2}\right)$ is 55 percent. Therefore, the ability of independent variable (variable $\mathrm{X}$ ) that is the effectiveness in explaining and giving related information to the dependent variable (variable $Y$ ) that is learning satisfaction that is equal to 55 percent, is high. While other factors that can explain and give related information to students' learning satisfaction in using e-learning that is equal to 45 percent, was not discussed in this study. 
Previous studies related to the effectiveness of the implementation of e-learning programs were conducted by other researchers, Al-rahmi and Othman [15], Pucel and Stertz [16], Sinclair and Kable [17], Bisri and Samsudi [18], Sary and Wildani [7] have similarities with this research that the effectiveness always have a significant positive effect on the purpose of the implementation of a program. In this study, the effectiveness of implementation of e-learning program has a significant positive effect on student's learning satisfaction. While previous studies related to the learning satisfaction conducted by other researchers such as Rahman [19], Dziuban [20], Setiadi and Suryani [21], Marlindawati [22] and Darmawan [10] have a little similarity that e-learning can help facilitate to learn to get more optimal results. In this research, it was proved by the percentage of items no 1 with the percentage of 80 percent, the item contains statement that "I feel helped by the e-learning program so that I am satisfied learning by using elearning." After investigating previous studies that have been conducted by some other researchers, the researchers argued that the effectiveness of the implementation of elearning program has a significant positive effect on the students' learning satisfaction. This result can reinforce prior researches.

\section{Conclusions}

This research proved a successful result because it showed that effectiveness has a significant positive effect on the students' learning satisfaction in using e-learning program, which can be said that $\mathrm{HO}$ hypothesis was rejected and $\mathrm{H} 1$ hypothesis was accepted. It can be concluded, when the effectiveness is higher, then the level of student satisfaction will be higher too. This study still has many shortcomings, so it is expected that the next researchers can be better and can develop this research by adding variables related to the effectiveness or satisfaction of learning and of course with more samples.

\section{References}

[1] Sasono, E. (2014). Manajemen Sumber Daya Manusia Perguruan Tinggi: Tantangan dan Kebutuhan. Jurnal STIE Semarang. 6(2), 64-75.

[2] Rusmini. (2012). Peningkatan Mutu Lembaga Pendidikan Tinggi Melalui Perguruan Tinggi. jurnal pendidikan.2(3), 11-23.

[3] Rohmawati, A. (2015). Efektivitas Pembelajaran. Jurnal Pendidikan Usia Dini, 9(1), 1531. 
[4] Siagian, S. P. (2001). Kepemimpinan Organisasi Dan Perilaku Administrasi. Jakarta: Gunung Agung.

[5] Asmira. (2016). Efektivitas Penerapan Absensi Finger Print Dalam Meningkatkan Disiplin Kerja Pegawai Di Kecamatan Anggana Kabupaten Kutai Kartanegara. Jurnal IImu Pemerintahan. 4(3), 1009-1022.

[6] Chatab, N. (2007). Profil Budaya Organisasi. Bandung: Alfabeta.

[7] Sary, F. P., \& Wildani. (2017). Pengaruh Efektivitas Penerapan Absensi RFID Terhadap Disiplin Kerja Karyawan (Studi Kasus Pada Telkom University). Journal ISCLO. Proceeding by ISCLO

[8] Topala, I., \& Tomozi, S. (2013). Learning Satisfaction: Validity and Realibiility Testing For Student Learning Satisfaction Questionare. Procedia Social and Behavioral, 380386.

[9] Prabowo, S. A. (2015). Analisis Kepuasan Siswa Terhadap Kegiatan Pembelajaran Biologi Pada Sekolah Formal Dan Lembaga Bimbingan Belajar Non-Formal Di Kota Madiun. Jurnal LPPM, 3(1), 31-35.

[10] Darmawan, F. (2015). Pengukuran Tingkat Kepuasan Pemanfaatan E-learning (Studi Kasus E-learning IF UNPAS). Journal Speed, 7(4), 64-70.

[11] Yazdi, M. (2012). E-learning Sebagai Media Pembelajaran Interaktif Berbasis Teknologi Informasi. Jurnal IImiah Forensic. 2(1), 143-152. Retrieved From Jurnal Untad

[12] Suwastika, I. W. (2017). Analisis Kepuasan Pengguna E-learning Menggunakan Metode End Using Computing Satisfaction. Jurnal Konfrensi Nasional Sistem dan Informatika. 558-562.

[13] Zikmund, W. G., Babin, B. J., Carr, J. C., \& Griffin, M. (2010). Business Research Method $\left(8^{\text {th }}\right.$ ed). South Western: Cengages Learning.

[14] Supardi. (2016). Aplikasi Statistika dalam Penelitian (5 ${ }^{\text {th }}$ ed). Jakarta: Change Publication.

[15] Waleed, A. M., Othman, M. S., \& Yusuf, L. M. (2015). The Effectiveness Of Using ELearning In Malaysian Higher Education: A Case Study Univesiti Teknologi Malaysia. mediteranian journal of social science. Mediteranian Journal Of Social Science. 6(5), 625-636.

[16] Pucel, D. J., \& sterz, T. F. (2005). Effectiveness Of And Study Satisfaction With Web Based Compared To Traditional In Service Teacher Education Courses. Journal Of STEM Teacher Education . 42(2), 7-22. 
[17] Sinclair, M., \& Kable, A. (2016). The effectiveness Of Internet Based E-learning on Clinican Behavior and Patient Outcomes: A Systematic Review. International Jurnal Nursing Study. 70-81.

[18] Bisri, K., \& Samsudi. (2009). Efektivitas Penggunaan Metode Pembelajaran E-learning Berbasis Browser Based Training Terhadap Prestasi Belajar Siswa Pada Kompetensi Pemeliharaan/Servis Manual dan Komponen. Jurnal PTM. 9(2), 37-41.

[19] Rahman, N. A., Hussein, N., \& Aluwi, A. H. (2015). Satisfaction On Blended Learning In a Public Higher Education Institution. Procedia Social and Behavioral Science. 211, 768-775.

[20] Dziuban, C., Mokal, P., Kramer, L., \& Thompson, J. (2012). Student Satisfaction With Online Learning In The Presence Of Ambivalence. Higher Education And Internet. $1-8$.

[21] Setiadi, D., Kurniasih, D. L., \& Rosdiana, I. (2015). Kepuasan Mahasiswa Dalam Penerapan Website Dengan Media E-learning/E-education Moodle Materi MIK 1. Jurnal Manajemen Informasi Kesehatan Indonesia. 3(1), 5-16.

[22] Marlindawati. (2016). Pengukuran Tingkat Kepuasan Pengguna E-learning Dengan Penerapan Model End Using Computing Satisfaction (EUCS). Jurnal IImiah Matrik. 18(1), 55-66. 